\title{
Interpersonal Meaning Analysis in the Tale's Story of Sabai Nan Aluih
}

\author{
Yenita Uswar, Nova Andriani ${ }^{1}$ \\ ${ }^{1}$ Universitas Potensi Utama, Medan, Indonesia
}

\begin{tabular}{|c|c|}
\hline ARTICLE INFO & ABSTRACT \\
\hline $\begin{array}{l}\text { Article history: } \\
\text { Received Jan 28, } 2020 \\
\text { Revised Mar 16, } 2020 \\
\text { Accepted May 19, } 2020\end{array}$ & \multirow{4}{*}{$\begin{array}{l}\text { Systemic Functional Linguistics (SFL) is a study of language which } \\
\text { views language as two characteristics, systemic and functional. With } \\
\text { using SFL, the researchers try to analyze the tale's story of Sabai Nan } \\
\text { Aluih. The research aim is to identify the interpersonal meaning } \\
\text { realized in that story and to reveal the speech function of language } \\
\text { use in that story. The research design of this analysis is descriptive } \\
\text { qualitative research. The object of this research is the interpersonal } \\
\text { meaning analysis of clauses as exchange in the tale of Sabai Nan } \\
\text { Aluih. The data of this research is the clauses as exchange in the story } \\
\text { of Sabai Nan Aluih. The source of data which is used in this research } \\
\text { is the documentation of the data research paper. The researchers use } \\
\text { document analysis from the story of Sabai Nan Aluih as collecting } \\
\text { data. The data is analyzed by using description method. In the } \\
\text { interpersonal analysis, declarative mood dominates almost the story, } \\
\text { it is about } 91 \% \text {. And, the data analysis of speech function is found in } \\
\text { the story of Sabai Nan Aluih, statement, question and command, in } \\
\text { where statement is domination from the story about } 94 \% \text {. Thus, it is } \\
\text { important that the using of interpersonal meaning and the speech } \\
\text { function of the story of Sabai Nana Aluih is as information. }\end{array}$} \\
\hline $\begin{array}{l}\text { Keywords: } \\
\text { SFL, } \\
\text { Interpersonal Meaning, } \\
\text { Speech Function, } \\
\text { The tale's story of Sabai Nan } \\
\text { Aluih }\end{array}$ & \\
\hline $\begin{array}{l}\text { Clonflict of Interest: } \\
\text { None }\end{array}$ & \\
\hline $\begin{array}{l}\text { Funding: } \\
\text { None }\end{array}$ & \\
\hline
\end{tabular}

Corresponding Author: Yenita Uswar, Universitas Potensi Utama, Medan, Indonesia. E-mail: nietha.pasca@gmail.com

Copyright (C) Association of Language Teachers in Southeast Asia. All rights reserved

\section{Introducation}

In the process of communication, human being will convey their messages by speaking or writing. Speaking is a form of communication which is used to convey the messages directly. There are speakers and listeners speaking to each other. Meanwhile, writing is a form of communication which needs media to convey the messages, such as, television, magazine, newspaper, etc., to convey the messages. There are writers and listeners or readers in the form of communication which use that media.

In the area of West Sumatra, Indonesia, there is a famous story in Minangnese call kaba (Minangkabau prose) in where always told by kaba artisans' long time ago. In the folklore it is told that Sabai nan Aluih is a beautiful girl but brave in defending arbitrariness.

The story is the folklore which addressing moral to the reader. The story of Sabai Nan Aluih includes the category of folklore which contains moral messages. In where, it can be used as guidelines in everyday life. At least, there are two moral messages that can be drawn from the story above, be brave in defending the truth, and what happened for the bad consequences of not being able to be grateful for God's blessings. 
In this research, researchers discuss about the interpersonal meaning the story of Sabai Nan Aluih. They use Systemic Functional Linguistics (SFL) as the method to analyze from the story of Sabai Nan Aluih. SFL is a language study which views language as two characteristics, systemic and functional. It is systemic because SFL uses the theory of meaning as a choice, by which a language or any other semiotic system is interpreted as networks of interlocking options (Halliday, 1994: 14). It emphasizes meaning as the fundamental element in analyzing language. Language is also functional because it is designed to explain how language is used.

In the scope of SFL, there are fundamental components of meaning called metafunction. According to Halliday, the functional components are ideational meaning, interpersonal meaning and textual meaning (1985: 13). Interpersonal meaning views language from the point of views of its function in the process of social interactions. Interpersonal meaning, according to Butt et al (2001:86) is one of the most basic interactive distinction is between using language to exchange information and using it to exchange goods and services. It means that there are centralized influence by discourse of tenor (who/what kind of person produced this text? For whom?).

Interpersonal meanings focus on language interactivity, and concern the ways we act which each other through language. In either spoken texts or written texts, an interlocutor expects to inform listeners/readers through the text. This means that each text has a relationship between providers and recipients of information.

The analysis of interpersonal meaning deals with two components. They are speech functions and mood structures. Speech function is a way of someone conveys the ideas in communication to make the listeners understand the ideas as well. Its function is to enable the exchange of roles in rhetorical interaction: statements, questions, offers and commands.

The analysis of interpersonal meaning deals with two components, are mood element and residue element of the clause. The mood element includes subject, finite, and/or mood adjunct; while the residue consists of predicator, complement, and some adjuncts such as mood, polarity, comment, vocative or circumstantial adjunct (Eggins, 1994:154-169).

The interpersonal functions play the role of setting up and maintaining social relations, and indicate the role of the participants in communication (Halliday, 2002). The interpersonal metafunction comprehends a tenor of text or interactivity that is again comprised with three components: the speaker/writer personal (whether the writer or speaker has a neutral attitude, which can be seen through the use of positive or negative language), social distance (how close the speakers are) and relative social status (whether they are equal in terms of power and knowledge on a subject). The writer analyzes the interpersonal meaning the story of Sabai Nan Aluih by looking deeply at Mood structure of the clause in the story. The speech is divided into clauses (clause-complex), where each will be analyzed interpersonally.

Researchers are interested to reveal the interpersonal meaning with using mood structure. For example:

Sabai Nan aluih adalah seorang gadis yang tinggal di hilir sungai Batang Agam di daerah Padang Tarok yang airnya jernih

Sabai Nan Aluih is a girl who lives in downstream of Batang Agam river in Padang Tarok area, where the water is clear.

Table 1. The Example of Mood Structure

\begin{tabular}{|c|l|c|c|}
\hline Sabai Nan Aluih & Was & $\begin{array}{l}\text { A girl who lives in downstream of Batang Agam } \\
\text { river in Padang Tarok area }\end{array}$ & $\begin{array}{l}\text { where the water is } \\
\text { clear }\end{array}$ \\
\hline Subject & Fin & Compliment & $\begin{array}{c}\text { Adjunct: } \\
\text { circumstantial }\end{array}$ \\
\hline \multicolumn{2}{|c|}{ Mood } & \multicolumn{2}{|c|}{ Residue } \\
\hline
\end{tabular}

The researchers use a declarative mood in the clause (1) as it is a statement so the function is giving information to the reader. The researchers try to state that Sabai Nan Aluih is as the Subject as the function of noun. Meanwhile, the Finite element is a verbal operator expressing tense and modality (Halliday, 1994:72). According to Halliday, the clause is "organized as an interactive event" (Halliday \& Matthiessen 2014, p. 134). The clause (1) can be interpreted that the main participant is actually "Sabai Nan Aluih" who is function as a Subject of Noun, so the clause explains that the story is not about the author himself, instead of the other person. The finite "was" indicates that the event happens in past time referring to her status and living. The complement "a girl who lives in downstream of Batang Agam river in Padang Tarok area," indicates the status and address her living in the story. "Where the water is clear" explain the circumstantial 
adjunct, in where it explains about the expression some circumstance relating to the process represented in the clause.

Eggins (1994:152) states that the mood structure of the clauses refers to the organization of the set of functional constituents including constituent subject. The mood structure of the clauses refers to the organization of asset of functional constituents including the constituent Subject. The component that gets bandied back and forth is what we call the MOOD element of the clause (we use capital letters to differentiate the MOOD constituent of the clause from the general term, Mood, which describes the overall structure of the clause). Another component is called the RESIDUE. We can already, then suggest the propositions can be divided into two functional constituents. The aims of this research are (1) to identify the interpersonal meaning realized in the story of Sabai Nan Aluih and (2) reveal the speech function of language use in the story of Sabai Nan Aluih.

\section{Method}

This research analysis uses the descriptive qualitative research method in purpose to identify the interpersonal meaning and to reveal the speech function of language use which is found in the story of Sabai Nan Aluih. The object of research is the interpersonal meaning analysis of clauses as exchange in the story of Sabai Nan Aluih. The data used in this study are the clauses as exchange in the short story of Sabai Nan Aluih. In this research, researchers use observation and documentation as the processing of method of collecting data. Then, they describe the interpretation of interpersonal meaning and speech function that is found in the story.

\section{Results and Discussion}

\subsection{Result}

There are 163 clauses as exchange found in the story of Sabai Nan Aluih. To enable researchers to identify the relationships among the participants in that story, the following research analysis has been conducted based on the perspective of interpersonal meaning by analyzing them with using of mood, modality and personal interest. It can be explained below:

\subsubsection{Interpersonal Meaning}

\section{a. Types of Mood}

There are three types of mood, namely declarative mood, interrogative mood and imperative mood. In the story of Sabai Nan Aluih, there two types of mood are found, declarative mood and interrogative mood. It has been elaborated as follows:

\section{Declarative Mood}

Declarative mood expressed the statement. The clause which is included into declarative mood is when the position of the subject is before the finite.

Data: Sabai Nan aluih adalah seorang seorang gadis, yang tinggal di hilir sungai Batang Agam di daerah Padang Tarok yang airnya jernih

Sabai Nan Aluih is a girl who lives in downstream of Batang Agam river in Padang Tarok area, where the water is clear.

Table 2. Mood Structure of Declarative Mood

\begin{tabular}{|c|c|c|c|}
\hline Sabai Nan Aluih & Was & $\begin{array}{l}\text { a girl who lives in downstream of Batang Agam } \\
\text { river in Padang Tarok area }\end{array}$ & $\begin{array}{l}\text { where the water is } \\
\text { clear }\end{array}$ \\
\hline Subject & Fin & Compliment & $\begin{array}{c}\text { Adjunct: } \\
\text { circumstantial }\end{array}$ \\
\hline \multicolumn{2}{|c|}{ Mood } & \multicolumn{2}{|c|}{ Residue } \\
\hline
\end{tabular}

From the mood structure above, it can be found that there is one clause in a sentence, Sabai Nan Aluih is a girl who lives in downstream of Batang Agam river in Padang Tarok area, where the water is clear. This clause is a statement. It can be identified by the position of the subjects (Sabai Nan Aluih) which is before the finites (was).

The interlocutor is the writer of the story, addressing to the readers. The relationship between the writer and the readers is the writer as the provider of information and the readers as the recipient of the information. Researchers provide the information to the readers about the existence of Sabai Nan Aluih as the main participant is the clauses above. The other information is that the living of the girl. 


\section{Imperative Mood}

The imperative mood is a verb form which gives a command. Commands can include orders, requests, advice, instructions, and warnings.

Data: Segera tembakkan senjatamu!

Fire your gun immediately!

Table 3. Mood Structure of Imperative Mood

\begin{tabular}{|c|c|c|}
\hline Fire & Your gun & Immediately \\
\hline Fin & Compliment & Adjunct: $\operatorname{mood}$ \\
\hline Mood & \multicolumn{2}{|c|}{ Residue } \\
\hline
\end{tabular}

From the mood structure above, it can be found that there is one clause in a sentence, fire your gun immediately. This clause is using command. It can be identified by the position of the finite (fire) which is before the complement (your gun).

The interlocutor is the writer of the story, addressing to readers. The relationship between the writer and the readers is the writer as the provider of information and the readers as the recipient of the information. The writer provides the information Rajo Nan Panjang's order which have to done by his bodyguard.

\section{Interrogative Mood}

Interrogative mood is expressed the question. The clause which is included in interrogative mood is when the position of the subject is after the finite.

Data: Baik, bagaimana kalau kita bertanding?

Well, how about we fight?

Table 4. Mood Structure of Interrogative Mood

\begin{tabular}{|l|l|l|l|}
\hline Well & How about & We & Compete? \\
\hline Adjunct: continuity & WH/ adjunct: circumstantial & Subject & Fin \\
\hline \multicolumn{2}{|c|}{ Residue } & \multicolumn{2}{|c}{ Mood } \\
\hline
\end{tabular}

From the mood structure above, it can be found that there is only one clause in a sentence. The clause is a question. It can be identified by the position of the subject (we) which is after the finite (how about).

The interlocutor is the writer of the story, addressing to the readers. The relationship between the writer and the readers are the writer as the recipient of the information and the readers as the provider of information. The writer asks for the readers to respond the opinion of the writer about Rajo Nan Panjang's challenging. The writer think that Rajo Nan Panjang's anger towards Rajo Babanding's words, then the writer asks to the readers whether the readers agree or not with the opinion.

\section{b. Modality}

Modality is classified into Modalization and Modulation.

\section{- Modalization}

Modalization is the proposition of modality used in a clause which explores the exchange of information. Modalization has two kinds of intermediate possibilities, namely probability and usually

Data: "Meskipun ia Nampak lembut, ia cukup mahir dalam bermain silat dan hatinya tegar sekeras batu karang, berhati-hatilah!"

Even though he seems gentle, he is quite skilled at playing silat and his heart is hard as a rock, be careful!"

From the data above contains the modal finite seems which carries the degree of middle probability. The participants are Rajo Nan Panjang and his bodyguard. The judgment of Rajo Nan Panjang to Rajo Babanding is afraid towards Rajo Babanding's ability in silat. The relationship between Rajo Nan Panjang 
and his bodyguard is the master has a higher degree than his bodyguard as he warned his bodyguard about Rajo Babanding without asking for anyone's suggestion.

\section{- Modulation}

Modulation is the proposal modality used in a clause which exchanges goods and services. Modulation has two kinds of intermediate possibilities depending on the speech function of command or offer. In command, it is the levels of obligation, while in an offer, it is the level of inclination.

Data: Dia tidak pergi sendiri tetapi ditemani oleh seseorang untuk berjaga-jaga bila Rajo Nan Panjang berbuat curang. Tetapi dia sendiri yang akan melawan Rajo Nan Panjang.

He went not alone but accompanied by someone to guard if Rajo Nan Panjang cheated him. But he would fight against Rajo Nan Panjang alone.

The clause above contains modal finite would which carries the level of high obligation. There is a relationship between the researchers and the man as the participant in the clause above. The writer's judgment towards Rajo Babanding is positive because it is just fine for the researchers that Rajo Babanding obligated something to other people. It is usual because Rajo Babanding is an honorable man due to a higher level to obligate something to other people.

\section{c. Personal Pronoun}

There are three types of personal pronoun; the first personal pronoun, the second personal pronoun and the third personal pronoun. All of the types of personal pronoun are found in the story of Sabai Nan Aluih.

\section{First Personal Pronouns}

The first personal pronoun includes I, my, me, we, our, and us.

Data: "Katakan pada majikanmu, bahwa aku menolak lamarannya, dan Sabai belum mau berumah tangga!"

"Tell your master, that $\boldsymbol{I}$ reject the proposal, and Sabai doesn't want to get married yet!"

The subject of the sentence above is "I" which is the first personal pronoun. "I" in this case is used in the direct sentence. "I" in the sentence above shows the character in the story along with other characters.

\section{Second Personal Pronouns}

The second personal pronoun includes you, you and your.

Data: "Rajo Babanding, kau telah menolak lamaranku untuk menyunting putrimu, Sabai".

"Rajo Babanding, you have refused my proposal to married with your daughter, Sabai".

The Subject "you" in the sentence above is the second personal pronoun. You in this case are used in the direct sentence. You in the sentence above show the direct involvement with other characters of the story.

\section{Third Personal Pronoun}

The third personal pronoun includes they, them, their, he, his, him, she, her, it, its. In the text story, personal pronouns used the most is the third personal pronoun

Data: Dia juga seorang pria yang sudah lanjut usia.

$$
\text { He was also an old man }
$$

The third personal pronouns are mostly used in the text. Therefore, the main character/participant of the text is not the researchers themselves but the other person. So the researchers are not involved at all as the character in the story.

\section{Speech Function}

The speech function which is found in the story of Sabai Nan Aluih is a statement that functions for giving information and questions that functions to ask/request for the information.

\section{a. Statements (giving information)}

Data: Adik Sabai Nan Aluih, Mangkutak Alam, mempunyai wajah yang tampan dan menarik.

Sabai Nan Aluih's younger brother, Mangkutak Alam, had a handsome and good looking man. 
The clause above is declarative clause, thus the clause is a statement. The clause gives the information about Sabai Nan Aluih brother who has a good looking and handsome Man.

\section{b. Imperatives (command)}

Data: "Katakan pada majikanmu, bahwa aku menolak lamarannya, dan Sabai belum mau berumah tangga!"

“Tell your master, that I reject the proposal, and Sabai doesn't want to get married yet!'

The clause above is the imperative clause, thus the clause is command. The clause gives the information about order Rajo Babanding to Rajo Nan Panjang's messenger towards Rajo Nan Panjang's proposal to his daughter.

\section{c. Questions (to ask information)}

Data: "Kenapa kamu diam saja"

"Why are you silent?"

The clause in the above is an interrogative clause therefore the form of the clause is a question. This clause asks for information about the researchers' opinion about Rajo Nan Panjang orders to Rajo Nan Kongkong. The researchers think that the power of Rajo Nan Panjang towards his bodyguard, thus the writer asks the reader whether the reader agrees or not with that opinion.

\subsection{Discussion}

From the data analysis, the researchers give the discussion in the form of the data analysis recapitulation. The recapitulations are shown as below:

Table 5. The percentage of Mood Types

\begin{tabular}{|c|c|c|c|}
\hline No & Mood of Types & Occurrences & Percentages \\
\hline 1. & Declarative Mood & 149 & $91 \%$ \\
\hline 2. & Imperative Mood & 9 & $6 \%$ \\
\hline 3. & Interrogative Mood & 5 & $3 \%$ \\
\hline \multicolumn{2}{|c|}{ Total } & 163 & $100 \%$ \\
\hline
\end{tabular}

From the table 5 above, it can be seen that from 163 clauses of Sabai Nan Aluih's story, there is 149 clause of Declarative Mood. There are also 9 clauses of Imperative mood and 5 clauses of Interrogative mood. It can be concluded that almost clauses in form of Declarative clause. It is about $91 \%$.

Table 6. The Percentage of Modality

\begin{tabular}{|c|c|c|c|}
\hline No & Modality & Occurrences & Percentages \\
\hline 1. & Modalization & 2 & $29 \%$ \\
\hline 2. & Modulation & 5 & $71 \%$ \\
\hline \multicolumn{2}{|c|}{ Total } & 7 & $100 \%$ \\
\hline
\end{tabular}

From the table 6 above, the data presents that from 163 clauses of Sabai Nan Aluih's story, it is just found 2 clauses using modalization and 5 clauses using modulation from that story.

Table 7. The Percentage of Deictic

\begin{tabular}{|c|c|c|c|}
\hline No & Deictic & Occurrences & Percentages \\
\hline 1. & Spatial & 8 & $33 \%$ \\
\hline 2. & Temporal & 16 & $67 \%$ \\
\hline \multicolumn{2}{|c|}{ Total } & 24 & $100 \%$ \\
\hline
\end{tabular}

From the table 7 above, the data presents that from 163 clauses of Sabai Nan Aluih's story, only 24 clauses using deictic. There are 8 clauses using spatial and 16 clauses using temporal deictic from that story. 
Table 8. the Percentage of Personal Pronoun

\begin{tabular}{|c|c|c|c|}
\hline No & Personal Pronoun & Occurrences & Percentages \\
\hline 1. & First & 20 & $16 \%$ \\
\hline 2. & Second & 21 & $17 \%$ \\
\hline 3. & Third & 82 & $67 \%$ \\
\hline \multicolumn{2}{|c|}{ Total } & 123 & $100 \%$ \\
\hline
\end{tabular}

From the table 6 above, it can be seen that from 123 Personal Pronouns, which is found in Sabai Nan Aluih's story, there are 20 first personal pronouns. There are also 21 second personal pronouns and 82 third personal pronouns. It can be concluded the using of third personal pronouns dominates in the story. It is about $67 \%$.

Table 9. The Percentage of Speech Function

\begin{tabular}{|c|c|c|c|}
\hline No. & Speech Function & Occurrences & Percentages \\
\hline 1. & Statement & 153 & $94 \%$ \\
\hline 2. & Question & 5 & $3 \%$ \\
\hline 4. & Command & 5 & $3 \%$ \\
\hline \multicolumn{2}{|c|}{ Total } & 163 & $100 \%$ \\
\hline
\end{tabular}

From the table 9 above, it can be seen that from 163 of speech function which is found in Sabai Nan Aluih's story, there are 149 clauses of statement. There are also 5 questions, 4 clauses of the offer and 5 clauses of command. It can be concluded the using of statement in speech function dominates in the story. It is about $91 \%$.

\section{Conclusion}

From the research finding and the discussion of interpersonal meaning and speech functions which is found in the story of Sabai Nan Aluih, the researchers can conclude that

1. After analyzing the type of mood that is found from the story, the declarative mood is the most using in the story of Sabai Nan Aluih, it is about $91 \%$. The writer as the interlocutor is the information provider and the readers are the recipient of information.

2. After analyzing the modality that is found from the story, the finite tense is less used in the story than modal finite tense, it reveals the position of the author for the readers. The writer is not trying to persuade readers because the genre of the text is narrative which functions only to entertain the readers.

3. After analyzing the personal pronoun that is found from the third personal pronoun is almost used in the whole story, it reveals the involvement between the writer and the participants in the text.

4. The writer is not involved at all as the character in the story. The main character/participant of the text story is not the writer but the other people.

5. There are three speech functions which are found in the story, they are statement, question and command. The analysis has found that statement mostly appears about $94 \%$ in the story meanwhile question and command is a little appearing. It means that from the story indicates that the main function of the text story is to give information.

\section{References}

Butt, D., Fahey, R., Spinks, S. \& Yallop, C. 2000. Using Functional Grammar: An Explorer's Guide (2 $2^{\text {nd }}$ Edition). Sydney: National Centre for English Language Teaching .

Eggins, S. 1994. An Introduction to Systemic Functional Linguistics. London: Pinter Publisher Ltd.

Halliday, M.A.K. 1985a. An Introduction to Functional Grammar. London: Edward Arnold Inc. 
Halliday, M.A.K. 1994. An Introduction to Functional Grammar 2nd Edition. London: Edward Arnold.

Halliday, M. A. K. 2002. An Introduction to Functional Grammar. Beijing: Foreign Language.

Halliday, M.A.K. \& C.M.I.M. Matthiessen (2014): An Introduction to Functional Grammar. London: Routledge. 4th ed. 